\title{
Deformation Monitoring in Korean Traditional Test-bed Hanok in Myongji University
}

\author{
Yeong-Min Kim \\ College of Architecture, Myongji University, South Korea
}

Copyright $@ 2015$ Horizon Research Publishing All rights reserved.

\begin{abstract}
This research performed deformation monitoring for a Korean traditional wooden house called a Hanok to figure out its long-term deformational characteristics and hence, to establish basic data for the maintenance and management of Hanok. The monitored buildings are composed of two different types of Hanok, one is a one-story traditional Hanok built by traditional construction method, and the other is a two-storied, new-styled Hanok built by modernized construction method. The vertical deflection of roof structural members was measured for about two years. The mean vertical deflection of the angle rafter, called Chuneo, which is located on the corner of eaves, is $10.0 \mathrm{~mm}$ in the traditional Hanok and $1.7 \mathrm{~mm}$ and $5.7 \mathrm{~mm}$ both in the new-styled Hanok's 1 st and 2nd roof, respectively. The traditional Hanok showed 2 5times more deflection than the new-styled Hanok, and this result can be deduced from the fact that the roof weight of the traditional Hanok is $2 \sim 3$ times more than that of the new-styled Hanok, so the traditional Hanok showed more long-term deflection than the new-styled Hanok.
\end{abstract}

Keywords Long-term, Deformation, Monitoring, Hanok

\section{Introduction}

The Korean traditional wooden house is called a Hanok, and it has a history of over 2,000 years. The main structure of a Hanok is a post and lintel wooden frame, and its wall is made of a soil, straw and twigs. The roof weight of traditional Hanok is about $5 \sim 10 \mathrm{kN} / \mathrm{m}^{2}$ which is comparatively very heavy compared to the ordinary modern wooden house of $2 \sim 3 \mathrm{kN} / \mathrm{m}^{2}$. The connections between structural members in a traditional Hanok are mainly mortise and tenon joints.

The traditional Hanok requires 2 3 times more construction cost and time than those of the ordinary modern wooden house, and it has some inconvenient aspects to live in for the contemporary people. To cope with these difficulties, a new-styled Hanok has been developed which is widely used nowadays, improves space design and requires low construction cost and time. The external appearance of a new-styled Hanok is somewhat similar to that of a traditional Hanok, but it shows differences in construction material and construction methods. The new-styled Hanok uses glued laminated wood as its structural member, contrary to raw wood, which was used in traditional Hanok. Also the new styled Hanok generally adopts steel plate and bolt joints as its connection methods to simplify construction, and hence, to reduce construction cost compared to the complex and time requiring mortise and tenon joints used in a traditional Hanok.

Research on the wooden structures has been performed consistently at home and abroad. For example, research in Korea was performed by Min et al. [1] for seismic analysis of a traditional, Korean, two-storied Hanok, and Han et al. [2] studied the mechanical performance of tenon joints. Research on the new-styled Hanok has just begun in the early 2010s. Kim [3] performed dynamic tests on a $1 / 4$ scale test model of a new-styled Hanok and extracted its natural frequency and compared that with the results from eigenvalue analysis. and Kim et al. [4] performed static loading test on a $1 / 4$ scale test model of a new-styled Hanok and evaluated rotational stiffness of new connection types which are used in the new-styled Hanok. Lee et al. [5] performed shaking table tests on the $1 / 15$ scale test model of both traditional and new-styled Hanok and compared their dynamic characteristics. Kim et al. [6] checked structural safety and serviceability of a new-styled Hanok built in Korea, 2012. In regard to research done on the monitoring of Korean traditional wooden house, Hwang [7] investigated the relationship between mechanical properties of wood and moisture contents, and Park et al. [8] measured the moisture contents of wooden columns and analyzed their distribution patterns. Kim [9] performed monitoring of the moisture contents for both Korean traditional Hanok and new-styled Hanok for about one and a half years and analyzed the moisture contents on three criteria; namely, column location, wood type and relative humidity. While, abroad, Kang et al. [10] evaluated stiffness of the mortise and tenon joint in Chinese traditional timber structure, Lindt et al. [11] performed shaking table test to evaluate seismic response of a six story light frame wooden building, and 
Fang et al. [12] performed full-scale shaking table test to analyze the load-displacement relationship for the ancient Chinese timber structure.

In this study, to establish the basic data for the maintenance and management of a Hanok, the long-term deformation of both a traditional and new-styled Hanok were measured for about two years, and the deformational characteristics were analyzed.

\section{Deformation Monitoring of test-bed Hanoks}

\subsection{Introduction to the Monitored Test-bed Hanoks}

The construction of the monitored test-bed Hanoks was started in March 2012 and completed in May 2012, in Myongji University, Korea. The test-bed Hanoks are composed of two types of Hanoks. One is shown in Fig. 1(a) which is a one-story traditional Hanok built by traditional construction method, and the other is shown in Fig. 1(b) which is a two-storied new-styled Hanok built by modernized construction method. The basic information of the two test-bed Hanoks is summarized in Table 1. In the traditional Hanok, raw wood and mortise and tenon joints are used, whereas in the new-styled Hanok glued laminated wood and steel plate and bolt joints are used as its structural members and connection method.

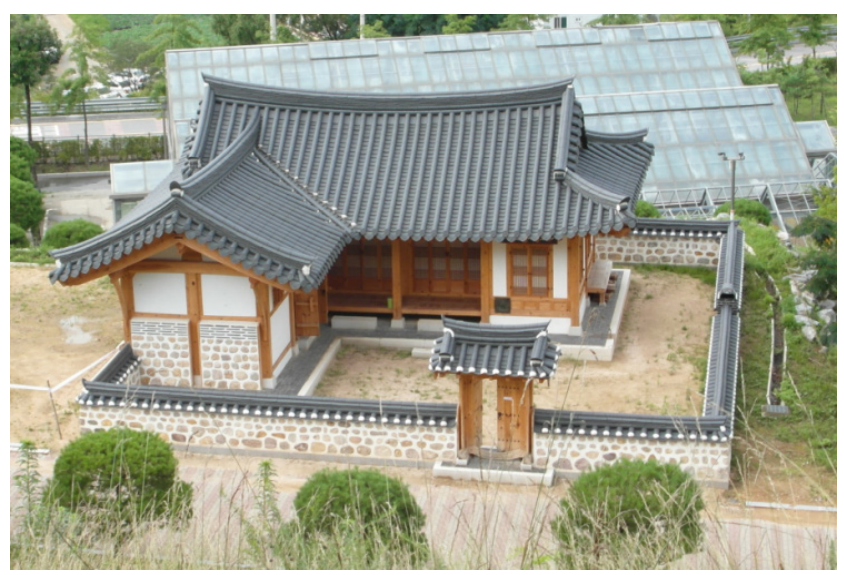

(a) Traditional Hanok

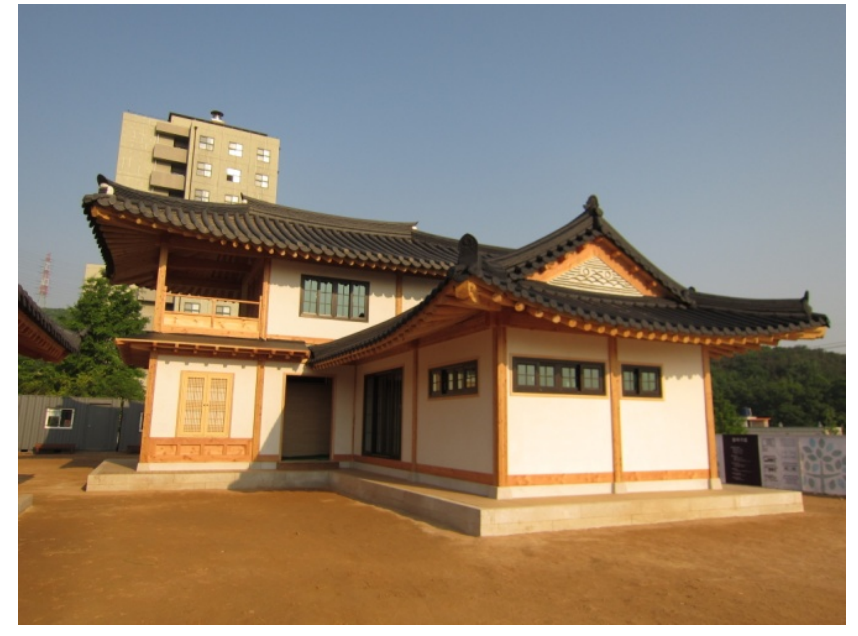

(b) New-styled Hanok

Figure 1. Test-bed Hanoks for deformation measurment

Table 1. Basic information for the monitored test-bed Hanoks

\begin{tabular}{cccc}
\hline $\begin{array}{c}\text { Type of } \\
\text { Hanok }\end{array}$ & Wood type & Connection type & $\begin{array}{c}\text { Year of } \\
\text { completion }\end{array}$ \\
\hline $\begin{array}{c}\text { Traditional } \\
\text { Hanok }\end{array}$ & raw wood & $\begin{array}{c}\text { mortise and tenon } \\
\text { joint }\end{array}$ & 2012.05 \\
\hline $\begin{array}{c}\text { New-styled } \\
\text { Hanok }\end{array}$ & $\begin{array}{c}\text { glued laminated } \\
\text { wood }\end{array}$ & $\begin{array}{c}\text { steel plate and bolt } \\
\text { joint }\end{array}$ & 2012.05 \\
\hline
\end{tabular}

\subsection{Plan for the Deformation Monitoring}

The monitoring plan is summarized in Table 2 . Deflection monitoring of structural members of the traditional and new-styled Hanoks was carried out every month during a two-year period, from August 2012 to August 2014. The horizontal roof structural members were monitored; that is, angle rafter (called Chuneo in Korea), plane rafter, and beam (called Dori in Korea). For each of the monitored members, vertical deflection was measured three times at the same position at every monitoring time, and the averaged value was used as its representative value.

Fig. 2 shows monitored members and their positions for both traditional and new-styled Hanoks. The deflection was monitored by measuring distance from the reference positon to the target position by using laser distance measuring device. The reference position of each monitored member is located just below of each target position. Fig. 3(a) shows scenes of measuring vertical deflection for the new-styled Hanok. The measuring device is shown in Fig. 3(b), it is from Leica Inc., and its model name is DISTO D5 with measurement error $\pm 1 \mathrm{~mm}$.

Table 2. Monitored members and monitoring periods for the test-bed Hanoks

\begin{tabular}{ccccc}
\hline \multirow{2}{*}{ Type of Hanok } & \multicolumn{3}{c}{ Monitored members } & Monitoring peirod \\
\cline { 2 - 5 } & $\begin{array}{c}\text { Angle rafter } \\
(\text { Chuneo })\end{array}$ & Plane rafter & $\begin{array}{c}\text { Beam } \\
\text { (Dori) }\end{array}$ & $2012.08 \sim 2014.08$ \\
\hline Traditional Hanok & 3 & 2 & 4 & $2012.08 \sim 2014.08$ \\
\hline New-styled Hanok & 5 & 2 & 4 & 2 \\
\hline
\end{tabular}



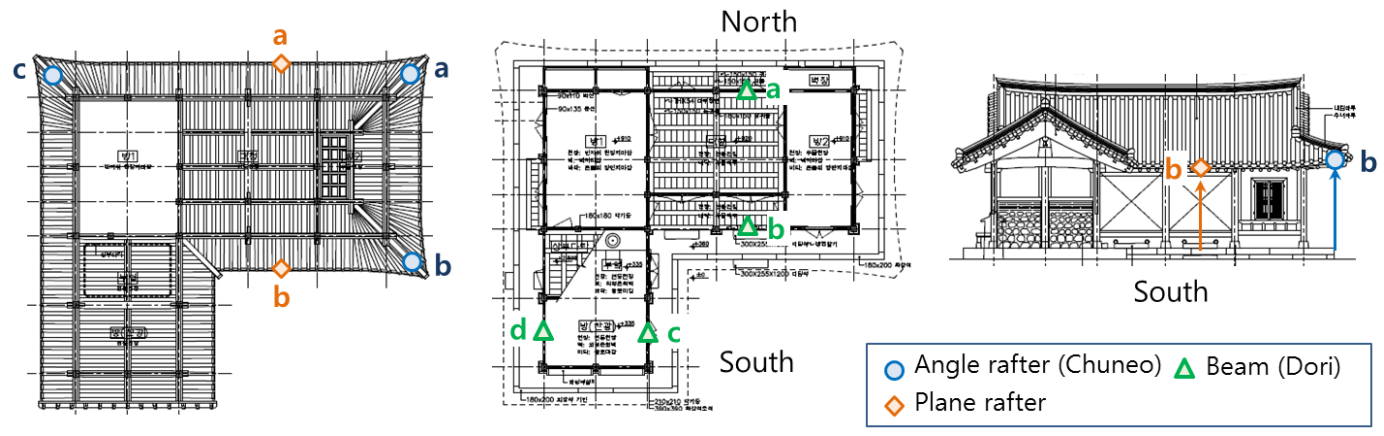

(a) Monitored members and their positions for traditional Hanok
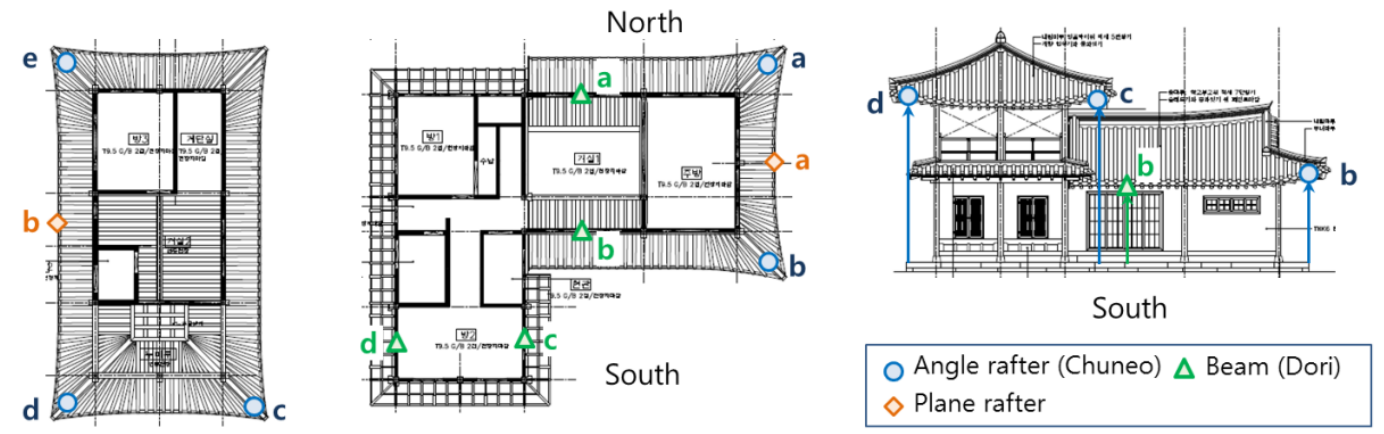

(b) Monitored members and their positions for new-styled Hanok

Figure 2. Monitored members and their positions for two test-bed Hanoks

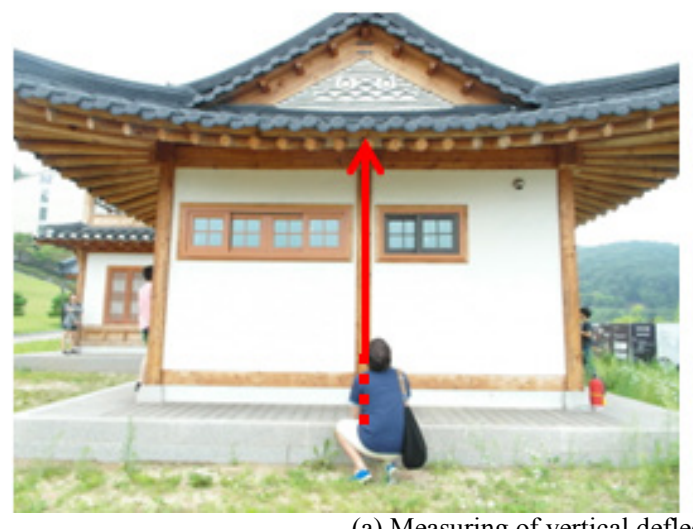

(a) Measuring of vertical deflection

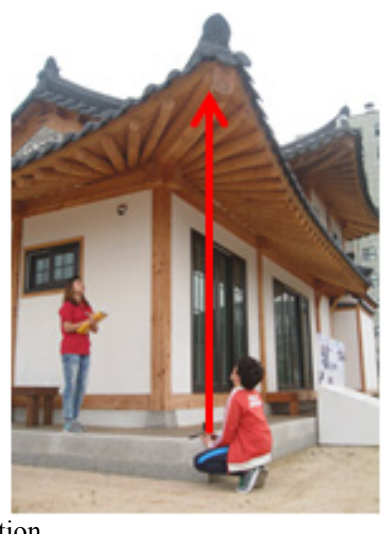

Figure 3. Vertical deflection measurement and measuring device

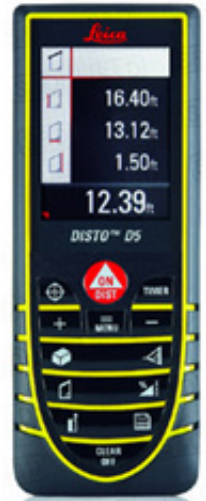

(b) Measuring device

Distance $(\mathrm{mm})$

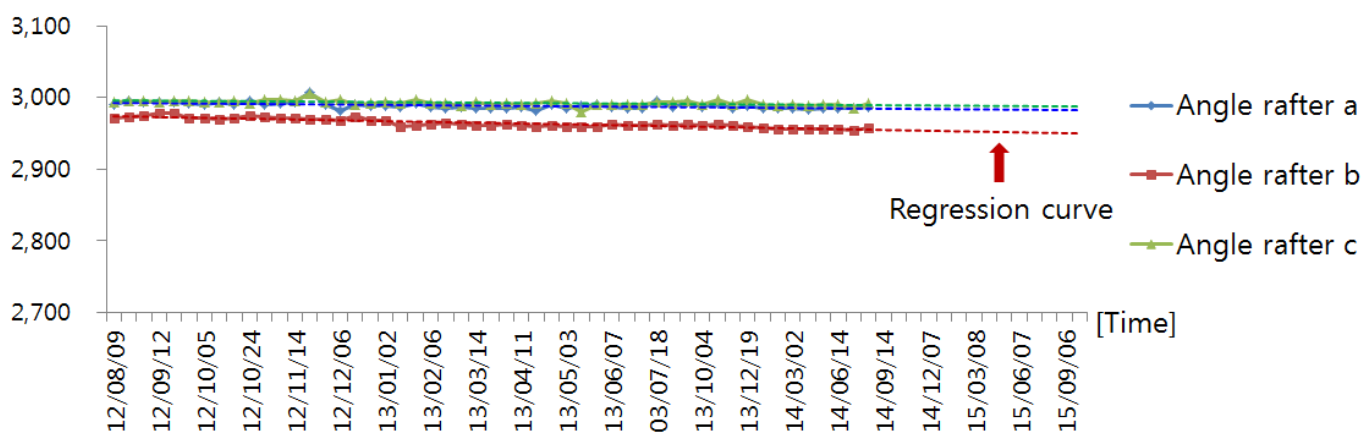

(a) Vertical distance of angle rafters(Chuneo) in 1st roof of the traditional Hanok 


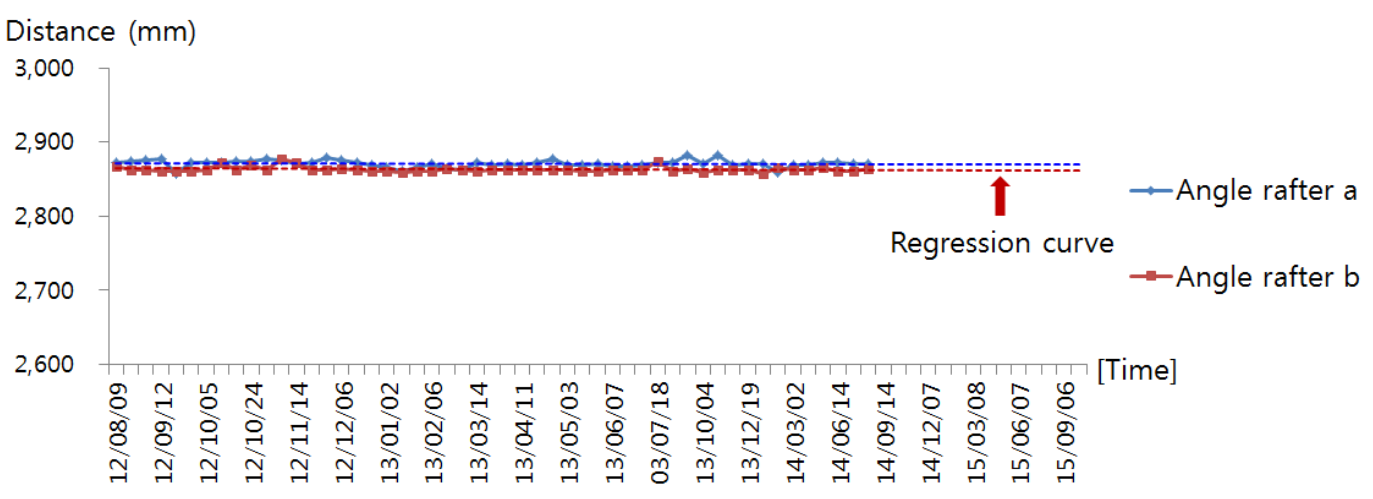

(b) Vertical distance of angle rafters(Chuneo) in 1st roof of the new-styled Hanok

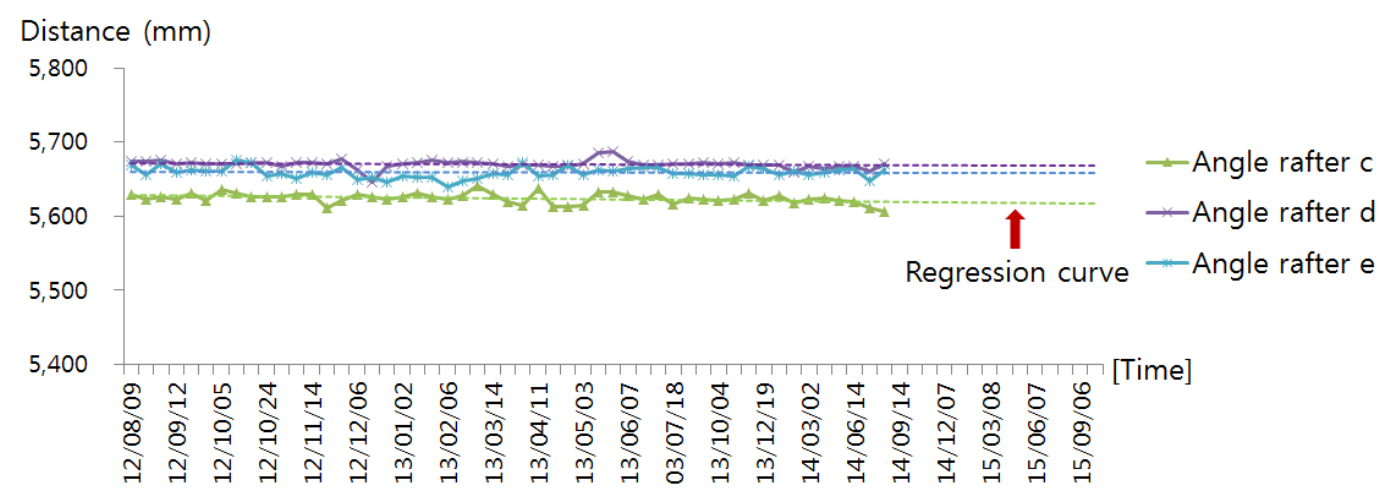

(c) Vertical distance of angle rafters(Chuneo) in 2nd roof of the new-styled Hanok

Figure 4. Vertical distance of angle rafters for two test-bed Hanoks

Table 3. Vertical deflection of angle rafters for two test-bed Hanoks

\begin{tabular}{|c|c|c|c|c|}
\hline $\begin{array}{l}\text { Type of } \\
\text { Hanok }\end{array}$ & Roof & Position & $\begin{array}{l}\text { Deflection } \\
\quad(\mathrm{mm})\end{array}$ & $\begin{array}{c}\text { Mean } \\
\text { deflection } \\
(\mathrm{mm})\end{array}$ \\
\hline \multirow{3}{*}{$\begin{array}{c}\text { Traditional } \\
\text { Hanok }\end{array}$} & \multirow{3}{*}{$\begin{array}{l}1 \mathrm{st} \\
\text { roof }\end{array}$} & $\mathrm{a}$ & 7.8 & \multirow{3}{*}{10.0} \\
\hline & & $\mathrm{b}$ & 17.7 & \\
\hline & & $\mathrm{c}$ & 4.4 & \\
\hline \multirow{5}{*}{$\begin{array}{l}\text { New-styled } \\
\text { Hanok }\end{array}$} & \multirow{2}{*}{$\begin{array}{l}1 \mathrm{st} \\
\text { roof }\end{array}$} & $\mathrm{a}$ & 2.0 & \multirow{2}{*}{1.7} \\
\hline & & $\mathrm{b}$ & 1.4 & \\
\hline & \multirow{3}{*}{$\begin{array}{l}2 \mathrm{nd} \\
\text { roof }\end{array}$} & $\mathrm{a}$ & 6.3 & \multirow{3}{*}{5.7} \\
\hline & & $\mathrm{b}$ & 4.4 & \\
\hline & & $\mathrm{c}$ & 6.3 & \\
\hline
\end{tabular}

\section{Analysis of the Monitored Results}

For three types of monitored members, only the angle rafter showed meaningful deflection, compared to the plane rafter and beam which showed little deflection. Fig. 4 shows the measuring distance of angle rafters during the entire monitoring period for both traditional and new-styled Hanok. Although there are small fluctuations in the graph, especially in the angle rafters of $2^{\text {nd }}$ roof of the new-styled Hanok as shown in Fig. 4(c), the overall graph shows a gradual decrease as time goes by. In Fig. 4, regression curves for the measured distance were also drawn to predict future trends of deflection.

In Table 3, the deflection results of the angle rafters were summarized. The mean vertical deflection of angle rafter, called Chuneo, which is located on the corner of eaves, is $10.0 \mathrm{~mm}$ in the traditional Hanok and $1.7 \mathrm{~mm}$ and $5.7 \mathrm{~mm}$ both in the new-styled Hanok's 1st and 2nd roof, respectively. The traditional Hanok showed 2 5 times more deflection than the new-styled Hanok. It can be deduced that the roof weight of the traditional Hanok weigh 2 3 times more than that of the new-styled Hanok, so the traditional Hanok showed more long-term deflection than the new-styled Hanok.

\section{Summary}

This research performed deformation monitoring for the Korean traditional wooden house called a Hanok, to establish the basic data for the maintenance and management of the Korean traditional wooden house. The monitored buildings are composed of two different types of Hanok, that is, a one-story traditional Hanok, and a two-storied new-styled Hanok. The vertical deflection of angle rafter, plane rafter and beam were measured for about two years. For three types of monitored members, only the angle rafter showed meaningful deflection. Although the measured data showed a small fluctuation, the overall data showed gradual decrease as time goes by. The angle rafters 
of traditional Hanok showed 2 5 times more deflection than the new-styled Hanok, and this result can be explained from the fact that the roof weight of the traditional Hanok weighs 2 3 times more than that of the new-styled Hanok, so the traditional Hanok showed more long-term deflection than the new-styled Hanok.

Together with deformation monitoring, moisture contents of wooden members were also monitored. Furthermore, another two years of monitoring period is scheduled. If roof deflection and moisture contents are analyzed together, it can be expected that the relationship among wooden member deformation, roof weight and moisture contents would be revealed.

\section{Acknowledgments}

This research was supported by a grant (14AUDP-B070934-02) from Urban and Architecture Research Program funded by Ministry of Land, Infrastructure and Transport Affairs of Korean Government.

\section{REFERENCES}

[1] K.W. Min, S.A. Park: Simple Structural Model and Seismic Analysis of Heunginjimum. Journal of the Architectural Institute of Korea : Structure \& Construction, 2011, 27(4): 23-30.

[2] J.S. Han, C.J. Kim: An Experimental Study on Mechanical Performance of Tenon for Analysis of Structural System and Modernization of Traditional Wooden Architecture. Journal of the Architectural Institute of Korea : Structure \& Construction, 2005, 21(4): 121-128.

[3] Y.M. Kim: Dynamic Experiments on a 1-4 Scale New-styled Korean Traditional Wooden House. Applied Mechanics and Materials, 2014, Vol 598: 743-746.
[4] Y. M. Kim, S. G. Lee, Evaluation of Connection Stiffness of Test-bed Hanok Using a 1/4 Scale Two-Storied Model, Journal of the Architectural Institute of Korea : Structure \& Construction, 2013, 29(12): 73-80.

[5] S.G. Lee, Y.M. Kim, J.E. Roh, S.H. Lee, S.S. Woo: Dynamic Characteristics of traditional and New Korean-style Houses According to Excitation Amplitude. Journal of the Architectural Institute of Korea : Structure \& Construction, 2013, 29(1) : 49-58.

[6] Y.M. Kim, J.H.Kim, S.G.Lee: Review Structural Safety and Propose Appropriate Sectional Size for New Traditional Korean-Style House. Journal of the Architectural Institute of Korea : Structure \& Construction, 2012, 28(5): 37-44.

[7] J. G. Hwang, The Moisture Content and Mechanical Characteristics of Wood, Journal of the Structure Diagnosis, 2011, 15(4): 3-6.

[8] C. H. Park, G. C. Kim, Study on Moisture Contents Distribution of Wooden Post Member by Precise Monitoring in Un-Bong Confusion School, Journal of the Korea Furniture Society, 2013, 21(1): 104-112.

[9] Y.M. Kim: Monitoring of Moisture Contents in Korean Traditional Wooden Houses. In Proceedings of the World Congress on Engineering 2014, London, England, June 2-4, 2014, pp.1298-1303.

[10] M.Kang, N.Yang, Q.Cha: Studies on Static Performance of Mortise and Tenon Joint in Traditional Column and Tie Construction Timber Structure. Electric Technology and Civil Engineering (ICETCE) 2011 International Conference, 2011, pp.6197-6200.

[11] J.W. Lindt, S.Pei, S.E. Pryor, H.Shimizu, H.Isoda: Experimental Seismic Response of a Full-scale Six-Story Light-Frame Wood Building. Journal of Structural Engineering, 2010, 136(10) : 1262-1272.

[12] D.P. Fang, S. Iwasaki, M.H. Yu, Q.P. Shen, Y. Miyamoto, H. Hikosaka: Ancient Chinese Timber Architecture I: Experimental Study. Journal of Structural Engineering, 2001, 127(11) : 1348-1357. 